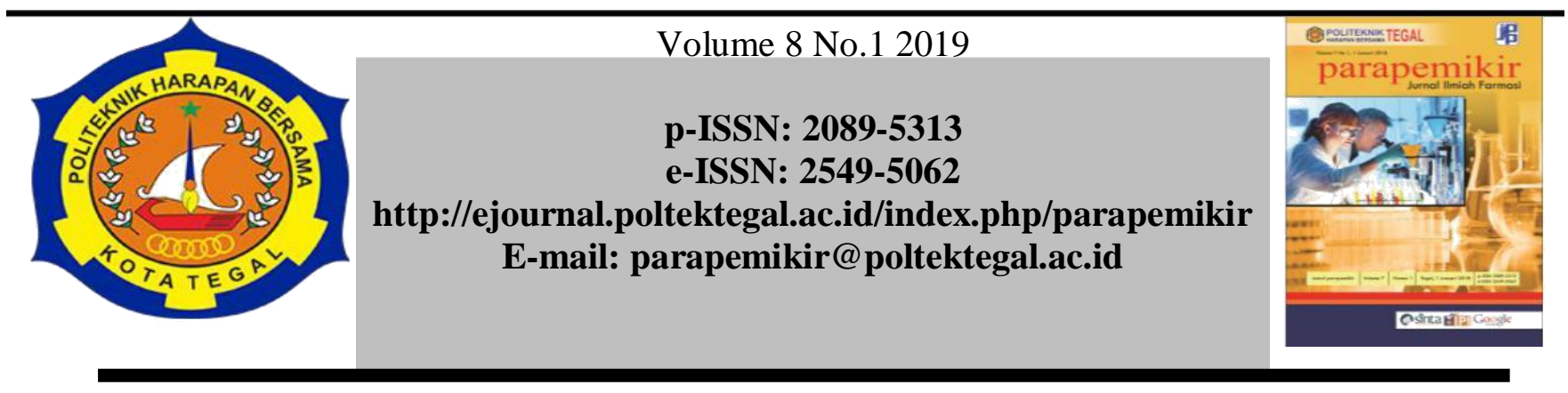

\title{
ISOLASI DAN IDENTIFIKASI SENYAWA KIMIA AKTIF KULIT BATANG KERSEN TERHADAP ARTEMIA SALINA
}

\author{
Muhammad walid ${ }^{1}$, Partomuan simanjuntak ${ }^{2}$, Ahmad darmawan ${ }^{3}$ \\ ${ }^{123}$ S1 Universitas Pancasila, J1. Srengseng Sawah, Jagakarsa, Jakarta 12640 \\ Email : suara.apoteker@gmail.com
}

\begin{tabular}{|c|c|}
\hline Article Info & Abstrak \\
\hline Article history: & \multirow{9}{*}{$\begin{array}{l}\text { Tanaman kersen (Muntingia calabura L.) banyak digunakan oleh masyarakat indonesia } \\
\text { untuk pengobatan berbagai penyakit seperti antikanker, antidiabetes, antioksidat, } \\
\text { antiplatelet dan hepatoprotektor. Tujuan penelitian ini adalah untuk mengetahui } \\
\text { struktur kimia yang terkandung didalam kulit batang kersen, (Muntingia calabura L.) } \\
\text { berdasarkan uji panduan aktivitas daya toksik dengan metode BSLT (Brine Shrimp } \\
\text { Lethality Test). Kulit batang kersen di maserasi dengan etanol } 96 \% \text { dan ekstraknya di } \\
\text { partisi dengan n-heksan etil asetat secara berturut-turut hingga menghasilkan ekstrak n- } \\
\text { heksan, etil asetat dan ekstrak air. Selanjutnya ektrak etil asetat yang mempunyai daya } \\
\text { toksik tertinggi (LD50 = } 29.00 \text { bpj) dilakukan pemurnian dengan kromatografi kolom } \\
\text { SiO2 : eluen (i) n-heksan - etil asetat = 20:1 hingga } 1: 1 \text {; (ii). n-heksan - etil asetat }= \\
\text { 5:1 menghasilkan fraksi } 4.5 .5 \text { sebagai isolat murni. Identifikasi dilakukan berdasarkan } \\
\text { interpretasi data spectra infra merah (FT-IR) dan spectra massa (LC-MS), dan } \\
\text { penelusuran pustaka, maka isolat murni (Fraksi 4.5.5) diprediksi sebagai senyawa 5- }\end{array}$} \\
\hline $\begin{array}{l}\text { Received Desmber } \\
2018\end{array}$ & \\
\hline Received in & \\
\hline revised form & \\
\hline Desember 2018 & \\
\hline Accepted Januari & \\
\hline 2019 & \\
\hline Available online & \\
\hline January 2019 & \\
\hline $\begin{array}{l}\text { Kata kunci: } \\
\text { Muntingia calabura } \\
\text { L.; Muntingiaceae; } \\
\text { toksisitas; Artemia } \\
\text { salina Leach; } 5 \text { - } \\
\text { (7,8-dimethoxy-3,4- } \\
\text { dihydro-2H- } \\
\text { lbenzopyran-2-yl)- } \\
\text { 2,3- }\end{array}$ & $\begin{array}{l}\text { (7,8-dimethoxy-3,4-dihydro-2H-1 benzopyran-2-yl)-2,3-dimethoxyphenol yang } \\
\text { mempunyai daya toksik terhadap larva udang Artemia salina Leach. sebesar LC50 = } \\
\text { 5.76 bpj. }\end{array}$ \\
\hline dimethoxyphenol. & abstract \\
\hline $\begin{array}{l}\text { Keywords: } \\
\text { Hypoglycemic, } \\
\text { Diabetes Mellitus, } \\
\text { Momordica } \\
\text { charantia, Apium } \\
\text { graveolens L. }\end{array}$ & $\begin{array}{l}\text { Kersen (Muntingia calabura L.) has been widely used by Indonesian people to cure } \\
\text { many diseases such as cancer, diabetes, and antioxidant, antiplateletes, and } \\
\text { hepatoprotector. The aim of this research is to discover chemical structure of } \\
\text { compounds contained in barks of Kersen (Muntingia calabura L.) based on their } \\
\text { toxicity by BSLT (Brine Shrimp Lethality Test) method. Barks of Kersen (Muntingia } \\
\text { calabura L.) were macerated by } 96 \% \text { ethanol followed by partition with n-hexane and } \\
\text { ethyl acetate successively to give n-hexane, ethyl acetate and water extracts. Ethyl } \\
\text { acetate extract which showed highest toxicity (LD50 = } 29.00 \text { ppm) was purified by } \\
\text { column chromatography using SiO2 with eluents (i). n-hexane - ethyl acetate = } 20: 1 \text { } \\
1 \text { : 1; (ii). n-hexane - ethyl acetate }=5: 1 \text { to give fraction } 4.4 .5 \text { as pure isolated } \\
\text { compound. Identification was done based on interpretation of infra red } \\
\text { spectrophotometry (FT-IR) and liquid chromatography-mass spectra (LC-MS) data, } \\
\text { and supported by references investigation. Finally, we were predicted fraction } 4.4 .5 \text {. as } \\
\text { 5-(7,8-dimethoxy-3,4-dihydro-2H-1benzopyran-2-yl)-2,3-dimethoxyphenol with LC50 } \\
=5.76 \text { ppm }\end{array}$ \\
\hline
\end{tabular}


Muhammad walid, Partomuan simanjuntak, Ahmad darmawan, Vol 8 (1) 2019 pp 56-60

\section{Alamat korespondensi:}

Prodi DIII Farmasi Politeknik Harapan Bersama Tegal

Gedung A Lt.3. Kampus 1

J1. Mataram No. 09 Kota Tegal, Kodepos 52122

Telp. (0283) 352000

p-ISSN: 2089-5313

E-mail: parapemikir_poltek@yahoo.com

e-ISSN: 2549-5062 


\section{Pendahuluan}

Penderita penyakit kanker di Indonesia tiap tahun terus meningkat. Menurut Yayasan Kanker Indonesia, penderita kanker di Indonesia pada tahun 2015 mencapai 1,2 juta kasus dan meningkat menjadi 1,3 juta kasus pada tahun 2016. Meningkatnya penderita kanker tersebut disebabkan oleh pola hidup yang tidak sehat, kurang mengkonsumsi buah dan sayur juga kurang berolahraga (Anonim, 2018).

Indonesia merupakan negara tropis yang kaya akan tanaman yang dapat digunakan sebagai bahan obat dan baru 1.000 spesies tanaman yang terdaftar pada Badan Pengawasan Obat dan Makanan (BPOM) (Anonim, 2005)..Tumbuhan yang dapat digunakan untuk pengobatan antara lainKersen (Muntingia calabura L.). Menurut penelitian sebelumnya yang dilakukan oleh Chen et al (2004), menemukan dua senyawa baru yaitu 8-hidroksi-7,3', ,', ,' tetrametoksiflavon dan 8,4'-dihidroksi-7,3',5'trimetoksiflavon, asam vanilat serta terdapat 13 senyawa lainnya.Tulung (2017), juga melaporkan kandungan senyawa bioaktif pada kulit batang kersen antara lain senyawa metabolit sekunder berupa flavonoid, polifenol, saponin, tanin dan juga memiliki kandungan vitamin C, dan beta karoten. Senyawa metabolit sekunder dalam tanaman kersen memiliki khasiat sebagai anti kanker, antioksidan,antiplatelet, hepatoprotektor,analgesik, antidiabetes (Werdhasari, 2014; Marimutu, 2014)

Flavonoid merupakan senyawa metabolit sekunder yang mempunyai bioaktivitas sebagai anti kanker, bekerja dengan cara mencegah terjadinya reaksi bergabungnya molekul karsinogenik yang menyebabkan kanker dengan DNA sehingga mencegah terjadinya kerusakan atau perubahan stuktur DNA (Chen, 2005; Tapas, 2008). Antioksidan merupakan senyawa yang dapat menetralkan radikal bebas dengan cara mendonorkan salah satu atum hidrogen (Senet, 2017).Zakaria et al (2011), telah membuktikan bahwa antioksidan pada tumbuhan karsen dapat menghambat poliferasi sel kanker dan memiliki antioksidan karena mengandung senyawa fenol yang tinggi.Tumbuhan yang mengandung senyawa metabolit sekunder dapat bersifat toksik,maka perlu dilakukan penelitian untuk mengetahui struktur senyawa kimia aktif yang terkandung dalam kulit batang kersen berdasarkan panduan uji aktivitas daya toksik dengan metode Brine Shrimp Lethality Test (BSLT).

\section{Metodologi Penelitian}

Objek yang yang akan di teliti dalam penelitian ini adalah isolasi dan identifikasi senyawa kimia aktif kulit batang kersen (Muntingia calabura L.) terhadap
Artemia salina Leach. dengan metode Brine Shrimp Lethality Test (BSLT).

Sampel yang diguanakan berupa ekstrak kulit batang tumbuhan kersen (Muntingiacalabura L.) dalam etanol 96\%. Simplisia diperoleh dari wilayah kecamatan Randudongkal, Kabupaten Pemalang Jawa Tengah dengan ketinggian tanah 212 meter dari permukaan laut (Anonim, 2016).

a. Cara Kerja

1). Pengambilan simplisia

Kulit batang tumbuhan kesen di cuci bersih menggunakan air mengalir, di sortasi basah, kemudian di keringkan dengan menggunakan sinar matahari langsung, sortasi kering dan dihaluskan. Simplisia yang di gunakan sebanyak 8.000 gram dan diperoleh simplisia kering sebanyak 3.000 gram.

2). Ekstraksi

Setelah simplisia kering kemudian dihaluskan dengan cara di blander, kemudian di ekstraksi dengan metode maserasi menggunakan etanol 96\%, selama 24 jam dengan sesekali diaduk-aduk, disaring dan diuapkan, hingga diperoleh ektrak etanol. Maserasi dilakukan pengulangan sebanyak tiga kali.

3). Partisi

Ekstrak kulit batang kersen dengan etanol 96\%, kemudian di partisi dengan n-heksana dan air dengan perbandingan 1:1. Lapisan n-heksana di tampung dan di evaporasi sehingga diperoleh ekstrak n-heksana dan dilakukan uji Brine Shrimp Lethality Test (BSLT), lapisan air dipartisi kembali menggunakan etil asetat, hingga diperoleh ekstrak etil asetat, diuji Brine Shrimp Lethality Test (BSLT), dan lapisan air di uji dengan Brine Shrimp Lethality Test (BSLT), hingga diperoleh senyawa kimia paling aktif.

4). Uji toksisitas

Hasil ekstraksi menggunakan n-heksana, etil asetat dan air kemudian dilakukan uji toksisitas menggunakan metode Brine Shrimp Lethality Test (BSLT), dengan pengulangan sebanyak tiga kali, hingga diperoleh ekstrak etil asetat yang memiliki LC50 tertinggi.

5). Proses isolasi

Sejumlah 10 gram ekstrak etil asetat difraksinasi dengan menggunakan kromatografi kolom, fase diam silika gel GF 254 dan fase gerak n-heksanaetil asetat dengan perbandingan 20:1 sampai 1:1 dilakukan secara gradien hingga diperoleh beberapa fraksi, kemudian dianalisa menggunakan kromatografi lapis tipis menggunakan fase gerak nheksana-etil asetat perbandingan 5:1. Penampakan bercak diperjelas dengan cara di semprot menggunakan serium sulfat. Hasil terbaik kemudian dikerok dan dilakukan fraksinasi kembali secara isokratik, hasil yang diperoleh kemudian di lakukan uji BSLT.

b. Identifikasi senyawa isolat

1). Fourier Transform-Infra Red

Isolat dari Fraksi yang memiliki senyawa kimia aktif pada ekstrak etil asetat kulit batang kersen, dilakukan uji identifikasi menggunakan Fourier Transform-Infra Red (FT-IR), dan dilihat gugus 
senyawa aktif pada bilangan panjang gelombang Fourier Transform-Infra Red (FT-IR).

\section{2). LC-MS}

Uji identifikasi menggunakan LC-MS pada isolat untuk menunjukkan adanya satu senyawa kimia dalam isolat dengan menunjukkan besarnya intensitas pada rentang waktu (rt) tertentu, senyawa kimia yang terkandung pada waktu retensi tersebut memberikan beberapa fragmentasi yang menunjukkan bobot molekul.

\section{HASIL DAN PEMBAHASAN}

Tujuan penelitian ini adalah untuk mengetahui struktur senyawa kimia aktif yang terkandung dalam kulit batang kersen (Muntingia calabura L.) berdasarkan panduan uji aktifitas daya toksik dengan metode Brine Shrimp Lethality Test (BSLT) dilakukan dengan beberapa tahap, antara lain proses pengambilan simplisia, ekstrasi, partisi, kromatografi lapis tipis, uji toksisitas, isolasi dan identifikasi senyawa kimia aktif.

Hasil yang diperoleh dari uji toksisitas ekstrak nheksana, etil asetat, dan air, ektrak etil asetat menunjukkan toksisitas paling tinggi dengan LC50 sebesar 29,00 bpj. Semakin tendah nilai LC50 maka semakin tinggi toksisitasnya. Besarnya toksisitas etil asetat dapat dilihat pada tabel 1.

Tabel 1.Uji Toksisita ekstrak partisi kulit batang kersen menggunakan n-heksan, etil asetat dan air.

\begin{tabular}{|c|c|c|c|c|c|c|}
\hline \multirow[t]{2}{*}{ Fraksi } & \multirow[t]{2}{*}{$\begin{array}{c}\text { Konsentrasi } \\
\text { (ppm) }\end{array}$} & \multicolumn{3}{|c|}{$\begin{array}{c}\text { Jumlah } \\
\text { yang mati } \\
\text { Replikasi }\end{array}$} & \multirow[t]{2}{*}{$\begin{array}{c}\text { Rata- } \\
\text { rata }\end{array}$} & \multirow[t]{2}{*}{$\begin{array}{l}\mathbf{L C}_{50} \\
\text { (bpj) }\end{array}$} \\
\hline & & I & II & III & & \\
\hline \multirow[t]{4}{*}{$1 n$-heksana } & 10 & 0 & 0 & 4 & 1,4 & \\
\hline & 100 & 3 & 4 & 8 & 5 & 521,53 \\
\hline & 1000 & 6 & 8 & 9 & 7,7 & \\
\hline & Kontrol & 0 & 0 & 0 & 0 & \\
\hline
\end{tabular}

\begin{tabular}{lllllll}
\hline 2 Etil asetat & 10 & 5 & 6 & 5 & 5,4 & \\
& 100 & 10 & 10 & 9 & 9,6 & $\mathbf{2 9 , 0 0}$ \\
& 1000 & 10 & 10 & 10 & 10 & \\
& Kontrol & 0 & 0 & 0 & 0 &
\end{tabular}

\begin{tabular}{lllllll}
\hline 3 Air & 10 & 6 & 7 & 2 & 5 & 49,65 \\
& 100 & 8 & 6 & 9 & 7,7 & \\
& 1000 & 10 & 10 & 10 & 10 & \\
& Kontrol & 0 & 0 & 0 & 0 & \\
& & & & & \\
\hline
\end{tabular}

Berdasarkan hasil uji toksisitas, maka ekstrak etil asetat memiliki toksisitas yang paling tinggi $(29,00$ bpj) sehingga dilakukan uji isolsi senyawa kimia paling aktif dari kulit batang kersen. Hasil isolasi diambil cuplikan yang paling jelas dan bersih agar diperoleh senyawa kimia yang murni,

Kemudian cuplikan tersebut dikerok dan hasil kerokan tersebut di fraksinasi kembali secara isokratik hingga diperoleh fraksi 4.4.5 sebagai isolat murni yang memiliki LC50 terendah sebesar 5,76. bpj(tabel. 2).

Tabel 2. Hasil Uji toksisitas beberapa fraksi isolasi ekstrak etil asetat

\begin{tabular}{|c|c|c|c|c|c|c|c|}
\hline \multirow[t]{2}{*}{ No } & \multirow[t]{2}{*}{ Fraksi } & \multirow[t]{2}{*}{$\begin{array}{c}\text { Konsentrasi } \\
\text { (ppm) }\end{array}$} & \multicolumn{3}{|c|}{$\begin{array}{c}\text { Jumlah yang mati } \\
\text { Replikasi }\end{array}$} & \multirow[t]{2}{*}{$\begin{array}{c}\text { Rata- } \\
\text { rata }\end{array}$} & \multirow[t]{2}{*}{$\begin{array}{l}\mathbf{L C}_{50} \\
\text { (bpj) }\end{array}$} \\
\hline & & & I & II & III & & \\
\hline \multirow[t]{4}{*}{1} & Fraksi 4.4.1 & 10 & 7 & 7 & 5 & 6,3 & 27,77 \\
\hline & & 100 & 8 & 9 & 9 & 8,6 & \\
\hline & & 1000 & 10 & 10 & 10 & 10 & \\
\hline & & Kontrol & 0 & 0 & 0 & 0 & \\
\hline \multirow[t]{4}{*}{2} & Fraksi 4.4 .2 & 10 & 3 & 3 & 3 & 3 & 475,67 \\
\hline & & 100 & 6 & 6 & 5 & 5,6 & \\
\hline & & 1000 & 8 & 7 & 7 & 7,3 & \\
\hline & & Kontrol & 0 & 0 & 0 & 0 & \\
\hline \multirow[t]{4}{*}{3} & Fraksi 4.4 .3 & 10 & 9 & 9 & 10 & 9,3 & 10,41 \\
\hline & & 100 & 9 & 10 & 10 & 9,6 & \\
\hline & & 1000 & 10 & 10 & 10 & 10 & \\
\hline & & Kontrol & 0 & 0 & 0 & 0 & \\
\hline \multirow[t]{4}{*}{4} & Fraksi 4.4 .4 & 10 & 5 & 5 & 3 & 4.3 & 86,09 \\
\hline & & 100 & 6 & 5 & 5 & 5,3 & \\
\hline & & 1000 & 10 & 10 & 10 & 10 & \\
\hline & & Kontrol & 0 & 0 & 0 & 0 & \\
\hline \multirow[t]{4}{*}{5} & Fraksi 4.4.5 & 10 & 10 & 10 & 10 & 10 & 5,76 \\
\hline & & 100 & 10 & 10 & 10 & 10 & \\
\hline & & 1000 & 10 & 10 & 10 & 10 & \\
\hline & & Kontrol & 0 & 0 & 0 & 0 & \\
\hline \multirow[t]{4}{*}{6} & Fraksi 4.4.6 & 10 & 9 & 9 & 10 & 9,3 & 6,68 \\
\hline & & 100 & 10 & 10 & 10 & 10 & \\
\hline & & 1000 & 10 & 10 & 10 & 10 & \\
\hline & & Kontrol & 0 & 0 & 0 & 0 & \\
\hline
\end{tabular}

Hasil isolasi senyawa kimia fraksi 4.4.5 kemudian dilakukan pengujian menggunakan Spectra Fourier Transform - Infra Red (FT-IR) untuk mengetahui gugus senyawa kimia berdasarkan bilangan panjang gelombangnya. Hasil interpretasi tersebut menunjukkan adanya spectra senyawa alkena yang terdapatpada panjang gelombang 1687,71 , eter pada panjang gelombang 1097,50 , alkana pada panjang gelombang 2941,44, senyawa aromatik pada panjang gelombang 1456,26 dan hidroksil pada panjang gelombang 4314,00. Berdasarkan hasil interpretasi tersebut menunjukkan adanya gugus hidroksil $(-\mathrm{OH})$, cicin benzena dan adanya gugus eter (-C-O-C-).

Hasil Spectra Fourier Transform - Infra Red (FT-IR) dapat dilihat pada gambar 1

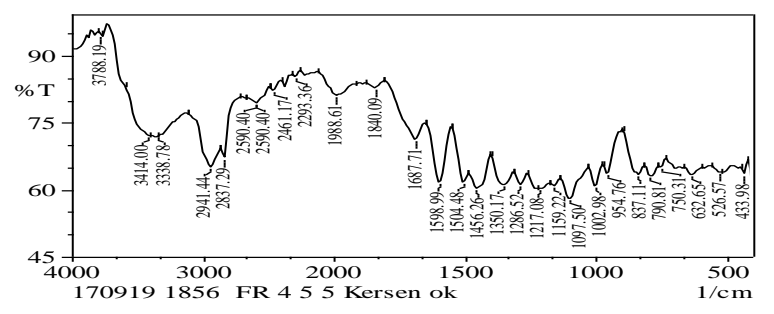

Gambar 1. Hasil Spectra Fourier Transform - Infra Red (FT-IR) fraksi 4.5.5

Hasil analisa kromatografi cair spektometri massa (LC-MS) senyawa kimia aktif fraksi 4.5.5 menunjukkan adanya satu senyawa di dalam 
isolate, ditandai dengan ditemukannya beberapa fragmentasi yang menunjukkan bobot molekul suatu senyawa. Hasil fragmentasi menunjukkan m/z 347,45 $(\mathrm{M}+\mathrm{H}), \mathrm{m} / \mathrm{z} 369,44(\mathrm{M}+\mathrm{Na}), \mathrm{m} / \mathrm{z} 693(\mathrm{M}+\mathrm{H})$ dan $\mathrm{m} / \mathrm{z} 715,88(2 \mathrm{M}+\mathrm{Na})$ ditunjukkan pada gambar 2 .

Berdasarkan data yang diperoleh dari LC-MS maka bobot molekul fraksi 4.5.5 sebesar 346 maka senyawa kimia aktif kulit batang kersen (Muntingia calabura L.) merupakan senyawa 5-(7,8-dimetoksi3,4-dihiro-2H-1benzopiran-2-yl)-2,3-dimetoksifenol atau dengan nama lain 5'-hidroksi-3',4', 7,8tetrametoksiflavan (Gambar 3.) yaitu senyawa yang termasuk dalam golongan senyawa flavonoid.

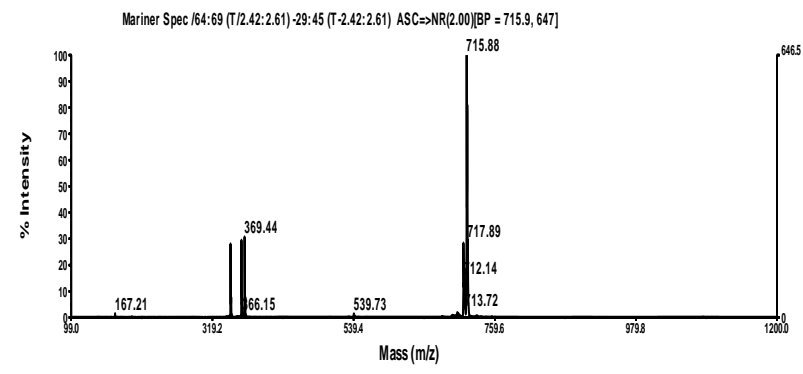

Gambar 2. Fragmentasi senyawa kimia aktif fraksi 4.5.5

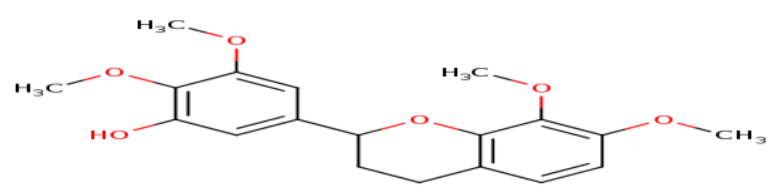

Gambar 3. senyawa 5-(7,8-dimetoksi-3,4-dihiro-2H1 benzopiran-2-yl)-2,3-dimetoksifenol

\section{KESIMPULAN}

Berdasar data-data hasil isolasi, purifikasi, dan identifikasi gugus fungsi utama bobot molekul terhadap isolat dari ekstrak etil asetat dapat disimpulkan bahwa kulit batang kersen (Muntingia calabura L.), dibandingkan dengan data referensi serta uji aktivitas toksisitas terhadap ekstrak fraksi isolat dapat disimpulkan bahwa fraksi aktif hasil pemurnian dengan kromatografi lapis tipis mempunyai LC50<1000 bpj, maka semua fraksi aktif terhadap Artemiasalina Leach. Namun demikian, fraksi yang paling aktif adalah fraksi 4.5.5 dengan LC50 sebesar 5,76 bpj. Identifikasi terhadap isolat fraksi 4.5.5 patut diduga merupakan senyawa metabolit sekunder dari golongan flavonoid yaitu 5(7,8-dimetoksi-3,4-dihidro-2H-1-benzopiran-2-yl)2,3-dimetoksifenol, yang mempunyai potensi untuk dikembangkan sebagai obat antikanker.

\section{UCAPAN TERIMAKASIH}

Ucapan terimakasih kami haturkan kepada Tuhan Yang Maha Esa atas ilmu yang diberikan kepada saya, juga kepada kedua pembimbing saya bapak Prof. (ris) Dr. Partomuan simanjuntak, M.Sc. dan bapak Dr. Akhmad Darmawan, M.Si

\section{REFERENSI}

[1] Anonim,http://yayasankankerindonesia.org /article/lembaga-kanker-dunia-serukankesetaraan-akses- kurangi-kematianprematur-kanker, 2018.

[2] Anonim, Standardisasi EkstrakTumbuhan Obat Indonesia, Salah Satu Tahapan Penting Dalam Pengembangan Obat Asli Indonesia, InfoPOM, Vol.6 No.4. Badan Pengawas Obat dan MakananRepublik Indonesia. 2005.

[3] Chen,J., et al, Cytotoxic Chalcones and Flavonoids from Leaves of Muntingia calabura.Departement of Pharmacy. Tajen Institute of Technology, Pingtung, Taiwan, 2005.

[4] Tulung et al, Analisis Fitokimiadan Uji Toksisitas dari Kulit Batang Kersen (Muntingia calabura). Program Studi Kimia Fakultas Matematika dan Ilmu Pengetahuan Alam Universitas Sam Ratulangi,Manado, 2017.

[5] Werdhasari A, Peran Antioksidan Bagi Kesehatan, Pusat Biomedis dan Teknologi Dasar KesehatanBalitbangkes. Kementrian kesehatan Republik Indonesia, 2014.

[6] Marimutu, Qualitative andquantitative study of phytochemicals in Muntingia calabura L. leaf and fruit. World journal of pharmaceutical research. Volume 3, 2014.

[7] Tapas, A. R., Sakarkar, D. M. \& Kakde, R.B.,Flavonoids as Nutraceutical: A Review. Tropical Journal of Pharmaceutical Research, 2008.

[8] Senet.M.R.M. et al, Kandungan total fenol dan flavonoid dari buah kersen (Muntingia calabura) serta aktivitas antioksidannya. Program study MIPA, Universitas Udayana, Bukit Jibaran, Badung, Bali, 2017.

[9] Zakaria ZA., 2007 Natural Medicines, Departement of Medicine and Healt Science, Universiti Putra Malaysia.

[10][10]Anonim, Pemalang dalam angka. Badan Pusat Statistik Kabupaten Pemalang, 2016 